\title{
Rapid Generation of Region-Specific Genomic Clones by Chromosome Microdissection: Isolation of DNA from a Region Frequently Deleted in Malignant Melanoma
}

\author{
Xin-Yuan Guan, " Paul S. Meltzer, † Jun Cao, and Jeffrey M. Trent††’" \\ Departments of Radiation Oncology, †Pediatrics and $¥$ Human Genetics, The University of Michigan Comprehensive Cancer Center, \\ The University of Michigan Medical Center, MSRB // C560, 1150 West Medical Center Drive, Ann Arbor, Michigan 48109-0668; and \\ *Committee on Genetics, University of Arizona, Tucson, Arizona 85724
}

Received May 7, 1992; revised July 22, 1992

\begin{abstract}
Malignant melanoma is frequently characterized by the deletion of the long arm of chromosome 6 (usually encompassing 6q16-q21). In an effort to saturate this region with DNA markers, microdissection and molecular cloning of DNA from banded human metaphases have been performed. This work was facilitated by the recent development of a novel chromosome microdissection scheme that omits microchemical manipulation of DNA. Microdissection was targeted on band $6 q 21$. Direct PCR amplification of dissected DNA was first used as a probe in chromosomal in situ hybridization of normal metaphases to confirm the specificity of material excised for cloning. A genomic library of $\mathbf{2 0 , 0 0 0}$ clones, which is highly enriched for sequences encompassing 6q21, was then constructed. Clones from this library have been mapped against a human-rodent somatic cell hybrid mapping panel that divides chromosome 6 into seven regions, confirming the localization of probes within the target region. Direct PCR amplification of DNA excised by microdissection greatly simplifies and facilitates this chromosome band-specific cloning strategy. The isolation of microclones from this region of chromosome 6 should assist in establishing a physical map of the melanoma deletion region. (c) 1992 Academic Press, Inc.
\end{abstract}

\section{INTRODUCTION}

Tumor suppressor genes (whose inactivation results in the release of a cell from normal growth control) have now been clearly documented to play an important role in the multistep process of malignant transformation (Knudson, 1971; Stanbridge, 1990; Marshall, 1991; Kinzler et al., 1991). Evidence suggesting the presence of tumor suppressor genes comes from several sources in-

\footnotetext{
1 To whom reprint requests should be addressed at Departments of Radiation Oncology and Human Genetics, The University of Michigan Medical School, MSRB II C560, 1150 West Medical Center Dr. Ann Arbor, MI 48109-0668.
}

cluding: (1) cytologically recognizable deletion of genomic material (Kinzler et al., 1991; Solomon et al., 1991); (2) evidence of allelic loss (assessed by restriction fragment length polymorphism [RFLP] analysis) (Vogelstein et al., 1989; Millikin et al., 1991); and (3) somatic cell hybridization experiments documenting reversion of tumorigenicity (Stanbridge, 1990; Trent et al., 1990). Nonrandom rearrangements of the long arm of chromosome 6 occur in several malignancies, including malignant melanoma (Mitelman, 1991). The most frequent alteration of chromosome 6 in melanoma is the simple deletion of the long arm of chromosome 6 occurring in excess of $60 \%$ of melanomas examined by banding analysis (Trent et al., 1983; Pathak et al., 1983; Trent et al., 1989). In melanoma, the single most frequent region of cytologic loss encompasses 6q16-q21. Loss of heterozygosity (LOH) for chromosome $6 q$ has also been documented in malignant melanoma (Millikin et al., 1991), and microcell-mediated chromosome transfer has provided biologic evidence for a tumor suppresser gene on $6 \mathrm{q}$ (Trent et al., 1990). To define more accurately the melanoma deletion region, a complete physical map of this region of chromosome 6 would be invaluable. Unfortunately, only a limited number of probes for the long arm of chromosome 6 are presently available, and numerous additional probes will be required to generate a physical map.

Several laboratories have previously utilized microdissection of metaphase chromosomes to generate bandspecific libraries (Lüdecke et al., 1989; Davis et al., 1990; Lengauer et al., 1991; Johnson, 1989). However, in contrast to the method utilized in this report, all of these studies have made use of restriction endonuclease digestion and DNA ligation steps, which, because of the exceedingly small amount of microdissected DNA, must be performed using microchemical techniques on a nanoliter microdrop contained in an oil chamber. In this report, microdissection of banded metaphase chromosomes was performed using a recently developed technique (Meltzer et al., 1992) that eliminates micro- 


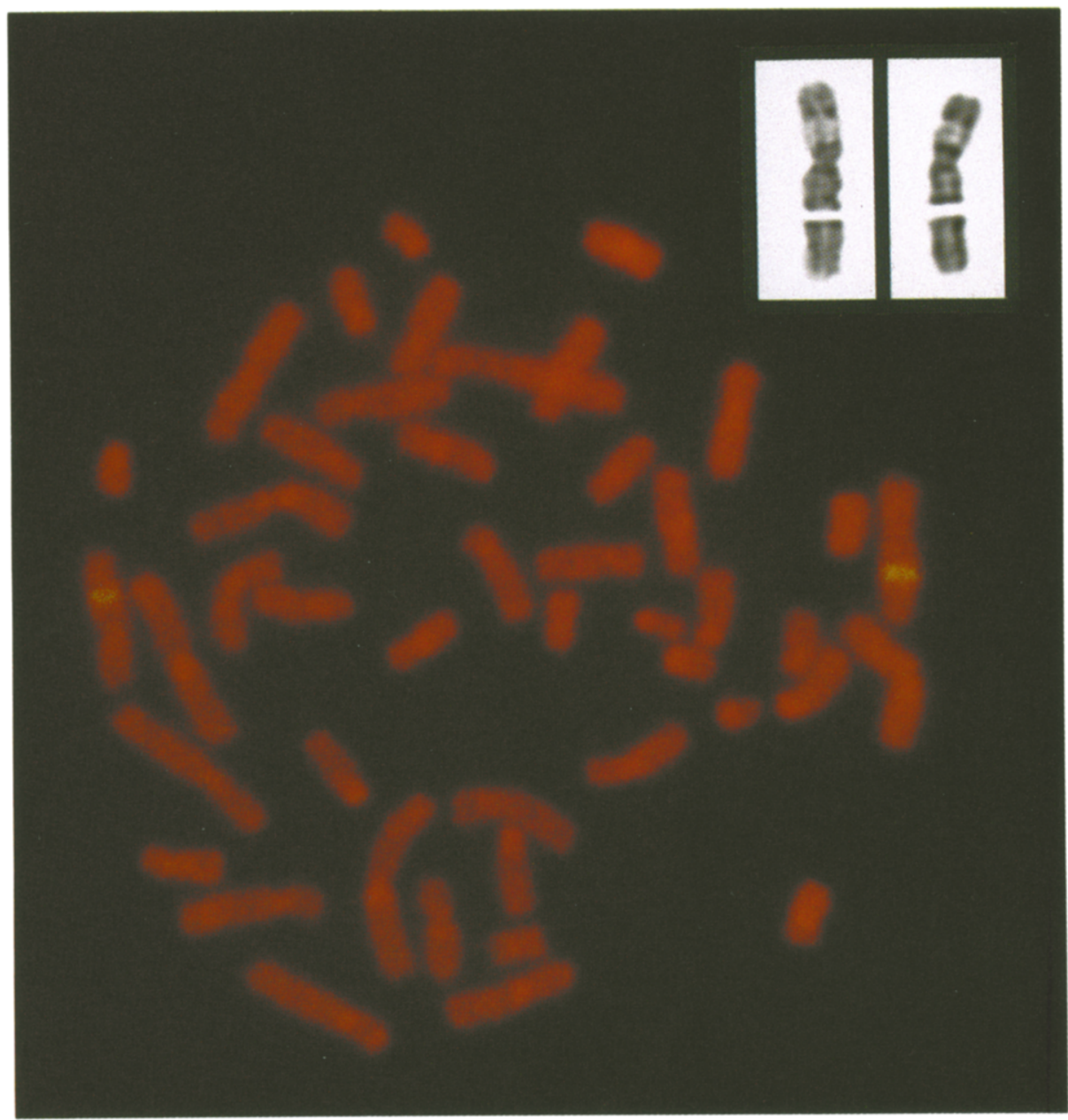

FIG. 1. Microdissection and fluorescence in situ hybridization (FISH) of targeted chromosome band 6q21. FISH using chromosome band 6q21 for a probe with FITC-fluorescent signals. (Inset) Two examples of GTG-banded human chromosomes after physical dissection encompassing band $6 \mathrm{q} 21$.

chemistry by direct PCR amplification of microdissected chromosomal fragments in conventional reaction volumes. The PCR product is then directly cloned, rapidly generating a band-specific library for further analysis. This procedure of direct enzymatic amplification of microdissected DNA followed by direct cloning provides the possibility of generating a significant number of band-specific probes. This report details the use of this procedure for the isolation and characterization of DNA microclones targeted to $6 \mathrm{q} 21$.

\section{MATERIALS AND METHODS}

Preparation of metaphase chromosomes. Phytohemagglutinin (PHA)-stimulated human lymphocyte cultures were arrested with colcemid and harvested as previously described (Trent and Thompson, 1987). Fixation in 3:1 methanol:acetic acid was performed $(\leqslant 2 \mathrm{~h})$ before making slides. Metaphases were spread on clean coverslips $(22 \times$ $60 \mathrm{~mm}$ ) and stored at $37^{\circ} \mathrm{C}$ for $2-3$ days. G-banding with trypsinGiemsa (GTG) was performed prior to microdissection.

Microdissection and amplification of chromosomal DNA. Microdissection was performed with glass microneedles controlled by a Narashige micromanipulator attached to an inverted microscope as previously described (Meltzer et al., 1992). The targeted region of dissection was 6q21. Prior to use, microneedles were treated with UV light for 5 min (Stratalinker, Stratagene). The dissected chromosome fragment (which adheres to the microneedle) was transferred to a 20- $\mu \mathrm{l}$ collecting drop (containing proteinase- $\mathrm{K} 50 \mu \mathrm{g} / \mathrm{ml}$ ) in a 0.5-ml microcentrifuge tube. A fresh microneedle was used for each fragment dissected. For this library, 40 copies were dissected, the collection drop was incubated first at $37^{\circ} \mathrm{C}$ for $1 \mathrm{~h}$ and then at $90^{\circ} \mathrm{C}$ for $10 \mathrm{~min}$ (to inactivate the proteinase-K). The components of the PCR reaction were then added to a final volume of $50 \mu \mathrm{l}$ in the same tube $(1.5 \mu M$ universal primer -CCGACTCGAGNNNNNNATGTGG- (Telenius et al., 1992), $200 \mu M$ each dNTP, $2 \mathrm{~m} M \mathrm{MgCl}_{2}, 50 \mathrm{~m} M$ KCl, $10 \mathrm{~m} M$ Tris$\mathrm{HCl}, \mathrm{pH} 8.4,0.1 \mathrm{mg} / \mathrm{ml}$ gelatin, and $2.5 \mathrm{U}$ Taq DNA polymerase (Perkin-Elmer/Cetus). The reaction was heated to $93^{\circ} \mathrm{C}$ for $4 \mathrm{~min}$ then cycled for 8 cycles at $94^{\circ} \mathrm{C}$ for $1 \mathrm{~min}, 1 \mathrm{~min}$ at $30^{\circ} \mathrm{C}$, and $3 \mathrm{~min}$ at $72^{\circ} \mathrm{C}$, followed by 30 cycles of $1 \mathrm{~min}$ at $94^{\circ} \mathrm{C}, 1 \mathrm{~min}$ at $56^{\circ} \mathrm{C}, 3 \mathrm{~min}$ at $72^{\circ} \mathrm{C}$, with a 10 -min final extension at $72^{\circ} \mathrm{C}$.

Fluorescence in situ hybridization (FISH). Amplified microdissected DNA $(2 \mu$ l) was labeled with biotin-11-dUTP in a secondary PCR reaction identical to that described above except for the addition of $20 \mu M$ biotin-11-dUTP. The reaction was continued for 12 cycles of $1 \mathrm{~min}$ at $94^{\circ} \mathrm{C}, 1 \mathrm{~min}$ at $56^{\circ} \mathrm{C}$, and $3 \mathrm{~min}$ at $72^{\circ} \mathrm{C}$, with a $10-\mathrm{min}$ final extension at $72^{\circ} \mathrm{C}$. The products of this reaction were purified with a Centricon 30 filter and used for FISH. Hybridization of the microdissection FISH probes followed our procedure described previously (Meltzer et al., 1992)), which is based upon the procedure of Pinkel et al. (1988). Briefly, for each hybridization, $100 \mathrm{ng}$ of probe was used in $10 \mu \mathrm{l}$ hybridization mixture containing $55 \%$ formamide, $2 \times \mathrm{SSC}$, and 


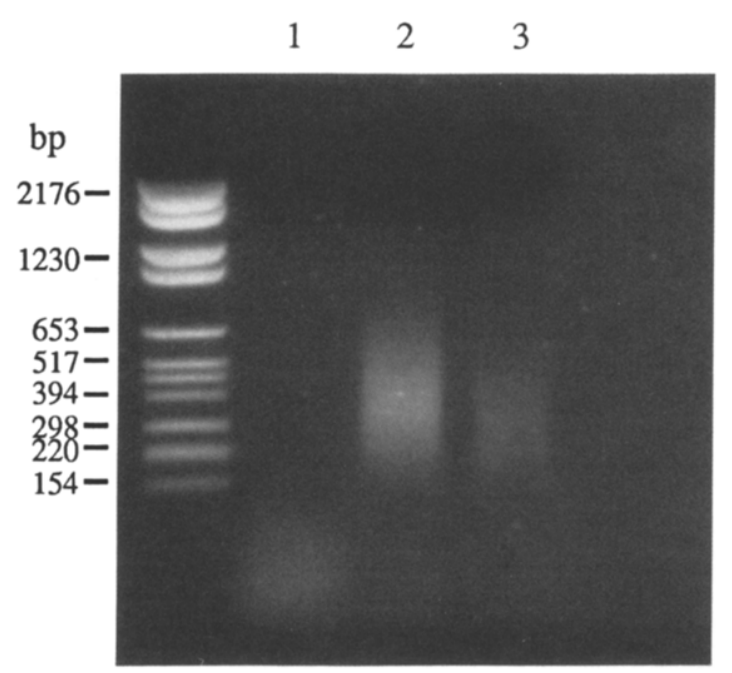

FIG. 2. PCR products from microdissection of chromosome band 6q21 resulting in a smear ranging from 200 to $900 \mathrm{bp}$ (Lane 3). Lane 1, PCR reaction with no DNA; lane 2, PCR product of $5 \mathrm{ng}$ total human DNA; lane 3, PCR product from microdissected chromosome fragments. PCR was carried out as previously described (Meltzer et al., 1992). PCR products $(10 \mu \mathrm{l})$ were size fractionated on a $1 \%$ agarose gel and stained with ethidium bromide.

$1 \mu \mathrm{g}$ human Cot 1 DNA (BRL). The slides with metaphase spreads were denatured in $70 \%$ formamide, $2 \times \mathrm{SSC}$ at $70^{\circ} \mathrm{C}$ for $2 \mathrm{~min}$, and then hybridized with probes at $37^{\circ} \mathrm{C}$ in a moist chamber overnight. The wash conditions for FISH were based upon those recommended by Pinkel et al. (1988) (two to three washes $50 \%$ formamide $45^{\circ} \mathrm{C}$; one wash $2 \times \mathrm{SSC} 45^{\circ} \mathrm{C}$; one wash PN Buffer $45^{\circ} \mathrm{C}$; one wash PN Buffer room temperature; avidin/anti-avidin FITC). Counterstaining was performed with $0.5 \mu \mathrm{g} / \mathrm{ml}$ propidium iodide (including an antifade solution) and was examined with a Zeiss Axiophot microscope equipped with a dual bandpass (fluorescein/rhodamine) filter.

Microcloning. The $\mathbf{P C R}$ products were directly inserted into a $\mathrm{T}$ tailed derivative of pGEM5fZ $(+)$ [kindly provided by Bernard Weisblum (Kovalic et al., 1991)]. This T-tail vector provides a single 3 T-overhang at the insertion site, which can be ligated with $3^{\prime} \mathrm{A}$-overhangs characteristically remaining on most Taq polymerase PCR products. For this library, 100-ng PCR products were ligated with $400 \mathrm{ng}$ vector in a $10-\mu \mathrm{l}$ volume ligation reaction at $12^{\circ} \mathrm{C}$ overnight. Ligation product $(1 \mu \mathrm{l})$ was then used to transform Escherichia coli by electro-

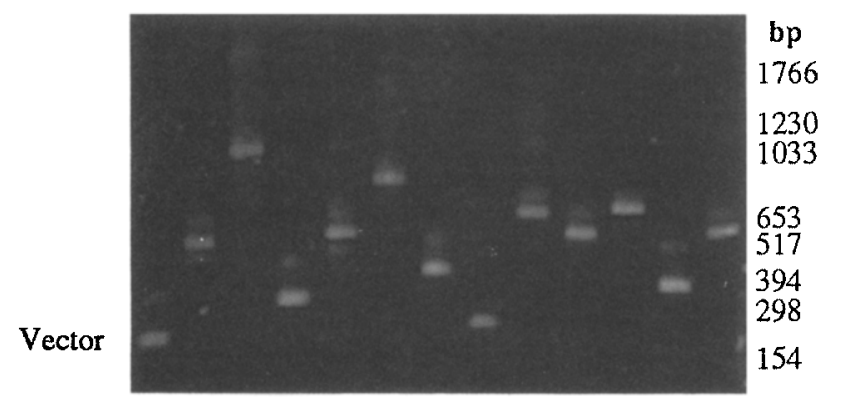

$\begin{array}{llllllllllll}21 & 42 & 33 & 8 & 49 & 13 & 56 & 50 & 38 & 58 & 54 & 34\end{array}$

\section{Clone Number}

FIG. 3. Inserts recovered by PCR from 12 individual microclones size fractionated on an $1 \%$ agarose gel and stained with ethidium bromide. These PCR products include $200 \mathrm{bp}$ of vector sequence as indicated in the left-hand lane. The average size of the microclones $(\sim 500$ bp) reflects the size distribution of the primary PCR product (see text).

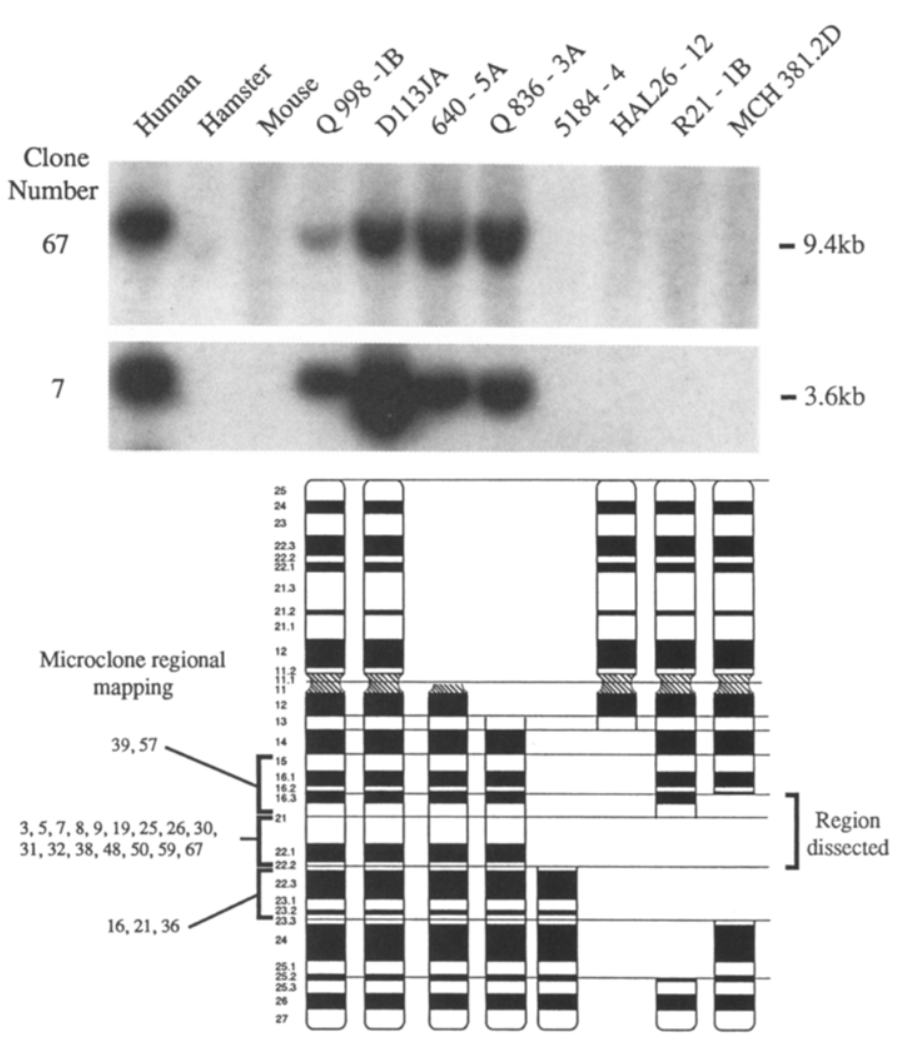

FIG. 4. Regional assignment of microclones. (Top) Southern blots using clones 67 and 7 as probes against EcoRI-digested DNA from a recently published somatic cell mapping panel comprised of eight cell lines (Meese et al., 1992). (Bottom) The chromosome 6 content of this panel is shown by representative idiograms of hybrid panel members. The region of chromosome 6 dissected is illustrated on the right of the idiograms for this hybrid mapping panel, with the regional assignment of microclones illustrated adjacent to the left of the idiograms. The majority of microclones $(16 / 21-80 \%)$ map to the midpoint of the dissected region (6q21), with some probes (as expected) mapping slightly proximal and distal. The assignments illustrated by the brackets are based upon the mapping of the DNA markers relative to the hybrid mapping panel. These results clearly confirm the FISH analysis and illustrate the significant enrichment of clones from this microdissection library within $6 \mathrm{q} 21-\mathrm{q} 22.2$.

poration. Inserts were recovered by PCR amplification of individual colonies using vector primers ( $\mathrm{T} 7$ and pUC/M13 reverse primers).

Regional chromosomal assignment of probes. A recently described series of somatic cell hybrids, which identifies seven regions along the long arm of chromosome 6 (Meese et al., 1992), was utilized to confirm the chromosomal position of a series of microclones. EcoRI-digested human genomic DNA from this panel was electrophoresed on $1 \%$ agarose gel, and the DNAs were then blotted onto a nylon filter (Schleicher \& Schull) by vacuum blotting. PCR-amplified inserts were gel purified and random primed using $\left[{ }^{32} \mathrm{P}\right] \mathrm{dCTP}$ (Feinberg and Vogelstein, 1983). Prehybridization and hybridization were as described elsewhere (Meese et al., 1989). All hybridized filters were washed in $0.1 \times \mathrm{SSC}, 0.1 \% \mathrm{SDS}$ at $65^{\circ} \mathrm{C}$ and autoradiographed for $3-5$ days at $-70^{\circ} \mathrm{C}$.

\section{RESULTS}

\section{Microdissection and FISH Analysis}

Based principally upon the compilation of cytogenetic information (Trent et al., 1989), and to a lesser degree 
LOH information (Millikin et al., 1991), the melanoma deletion region is assumed to encompass $6 q 16-q 21$. Accordingly, dissections for this library were carried out in an effort to ensure the generation of clones within this interval. Examples of metaphase chromosomes following physical microdissection encompassing $6 \mathrm{q} 21$ are shown in the inset to Fig. 1. Figure 1 also illustrates the results using the direct PCR-amplified dissected DNA (labeled with biotin-11-dUTP) as a probe in fluorescence in situ suppression hybridization (FISH). The results clearly confirm the sublocalization of the labeled DNA probe to the dissected region.

\section{Microclone Analysis}

Figure 2 illustrates the size distribution of PCR-amplified DNA from dissected fragments. The negative control (no DNA) was blank after PCR using the universal primer (Telenius et al., 1992), while both a positive control (5 $\mathrm{ng}$ total human DNA) and dissected DNA resulted in a smear ranging from $\sim 100-900 \mathrm{bp}$. PCR products were then directly inserted into a T-tailed derivative of pGEM5fZ(+) (Kovalic et al., 1991), generating a library of 20,000 clones. Examples of 12 clones from this library are shown in Fig. 3, with representative insert sizes ranging from 50 to $800 \mathrm{bp}$.

Forty-one of these microclones were radiolabeled and tested as probes against Southern blots. Of these 41 probes, $21 / 41(51 \%)$ generated single-copy hybridization signals, 9/41 (22\%) contained repetitive DNA, and 11/ $41(27 \%)$ failed to provide a detectable signal on hybridization to human DNA. The 21 single-copy probes ranged in size from 350 to $620 \mathrm{bp}$ with an average size of approximately $500 \mathrm{bp}$. The chromosomal sublocalization of the 21 single-copy microclones was confirmed by mapping relative to our recently published (Meese et al., 1992) chromosome 6 somatic cell hybrid panel. Figure 4 illustrates the pattern of hybridization of microclones to Southern blots of this mapping panel, which is composed of eight cell lines. The chromosomal content of these hybrids that subdivide the long arm of chromosome 6 into seven different regions is illustrated in the lower portion of Fig. 4. The targeted region of dissection was 6 q21, with the majority of probes tightly distributed around the dissected region and no clone originating from a chromosome other than 6 . Although redundancy is expected in a library generated by PCR, each of the 21 probes tested recognized a distinct restriction fragment in human DNA.

\section{DISCUSSION}

Chromosome microdissection as described in this report is an extremely useful approach to generate bandspecific libraries for physical mapping. This report describes a novel method for direct amplification and cloning of the microdissected template DNA, which eliminates the necessity for microchemical manipulations. This study documents the feasibility of this signifi- cantly simplified approach for generating a large number of region-specific probes in a short period of time. A further increase in rapidity is gained by testing the primary microdissection PCR product in FISH experiments. The localization and intensity of the FISH signal confirm the specificity of the library and give a preliminary indication of its quality. Therefore, the time-consuming process of testing individual microclones by Southern blot analysis is reserved for microdissection PCR products, which are already known to contain significant sequence representation from the targeted chromosomal region.

This 6q DNA microclone library should be useful for the long-range physical mapping of the melanoma deletion region of chromosome 6 . Further, the size of these clones is convenient for sequencing without subcloning and their density should be sufficient to assist significantly in the construction of a saturation STS map of 6q21 with corresponding YAC clones. Additionally, studies are under way to utilize the primary PCR-amplified microdissection material directly for library screening to isolate region-specific cosmid or YAC clones (unpublished data of authors). Finally, comparison of our results with those of other investigators who use microchemical approaches (Hampton et al., 1991; Senger et al., 1990; Davis et al., 1990) suggests that our library contains a proportion of useful clones at least equivalent to that obtained by these more biochemically rigorous methods.

Further studies will include continued characterization of microclones from the 6q21 library, as well as the utilization of the pooled library in FISH analysis of melanoma tumors, in an effort to confirm the presence of clones within the melanoma deletion region.

\section{ACKNOWLEDGMENTS}

This work was supported in part by PHHS Grant R37-CA-29476 (J.M.T.) and a research grant from the Amoco Technology Company, Naperville, Illinois.

\section{REFERENCES}

Davis, L. M., Senger, G., Lüdecke, H. J., Claussen, U., Horsthemke, B., Zhang, S. S., Metzroth, B., Hohenfellner, K., Zable, B., and Shows, T. B. (1990). Somatic cell hybrid and long-range physical mapping of $11 \mathrm{p} 13$ microdissected genomic clones. Proc. Natl. Acad. Sci. USA 87: 7005-7009.

Feinberg, A. P., and Vogelstein, B. (1983). A technique for radiolabeling DNA restriction endonuclease fragments to high specific activity. Anal. Biochem. 132: 6-13.

Hampton, G., Leuteritz, G., Lüdecke, H. J., Senger, G., Trautmann U., Thomas, H., Solomon, E., Bodmer, W. F., Horsthemke, B., Claussen, U., and Ballhausen, W. G. (1991). Characterization and mapping of microdissected genomic clones from the adenomatous polyposis coli (APC) region. Genomics 11: 247-251.

Johnson, D. H. (1989). Molecular cloning of DNA from specific chromosomal regions by microdissection and sequence-independent amplification of DNA. Genomics 6: 243-251.

Kinzler, K. W., Nilbert, M. C., Vogelstein, B., Bryan, T. M., Levy, D. B., Smith, K. J., Preisinger, A. C., Hamilton, S. R., Hedge, P., Markham, A., Carlson, M., Joslyn, G., Groden, J., White, R., Miki, 
Y., Miyoshi, Y., Nishisho, I., and Nakamura, Y. (1991). Identification of a gene located at chromosome 5q21 that is mutated in colorectal cancers. Science 251: 1366-1370.

Knudson, A. G. (1971). Mutations and cancer: Statistical study of retinoblastoma. Proc. Natl. Acad. Sci. USA 68: 820-823.

Kovalic, D., Kwak, J. H., and Weisblum, B. (1991). General method for direct cloning of DNA fragments generated by the polymerse chain reaction. Nucleic Acids Res. 19(16): 4560.

Lengauer, C., Eckelt, A., Weith, A., Endlich, N., Ponelies, N., Lichter, P., Greulich, K. O., and Cremer, T. (1991). Painting of defined chromosomal regions by in situ suppression hybridization of libraries from laser-microdissected chromosomes. Cytogenet. Cell Genet. 56: 27-30.

Lüdecke, H. J., Senger, G., Claussen, U., and Horsthemke, B. (1989). Cloning defined regions of the human genome by microdissection of banded chromosomes and enzymatic amplification. Nature 338: 348-350.

Marshall, C. J. (1991). Tumor suppressor genes. Cell 64: 313-326.

Meese, E., Meltzer, P. S., Witkowski, C. M., and Trent, J. M. (1989). Molecular mapping of the oncogene MYB and rearrangements in malignant melanoma. Genes Chrom. Cancer 1: 88-94.

Meese, E., Witkowski, C. M., Zoghbi, H. Y., Stanbridge, E. J., Meltzer, P. S., and Trent, J. M. (1992). Development and utilization of a somatic cell hybrid mapping panel to assign NotI linking probes to the long arm of human chromosome 6. Genomics 12: 542-548.

Meltzer, P. S., Guan, X.-Y., Burgess, A., and Trent, J. M. (1992). Rapid generation of region specific probes by chromosome microdissection and their application. Nature Genet. 1: 24-28.

Millikin, D., Meese, E., Vogelstein, B., Witkowski, C., and Trent, J. (1991). Loss of heterozygosity for loci on the long arm of chromosome 6 in human malignant melanoma. Cancer Res. 51: 5449-5453.

Mitelman, F. (1991). "Catalog of Chromosome Aberrations in Cancer," 4th ed., pp. 393-474, Wiley-Liss, New York.

Pathak, S., Drwings, H. L., and Hsu, T. C. (1983). Involvement of chromosome 6 in rearrangements in human malignant melanoma. Cytogenet. Cell Genet 36: 573 .

Pinkel, D., Landegent, J., Collins, C., Fuscoe, J., Segraves, R., Lucas, J., and Gray, J. (1988). Flourescence in situ hybridization with human chromosome-specific libraries: Detection of trisomy 21 and translocation of chromosome 4, Proc. Natl. Acad. Sci. USA 85 9138-9142.

Senger, G., Lüdecke, H. G., Horsthemke, B., and Claussen, U. (1990) Microdissection of banded human chromosomes. Hum. Genet. 84: $507-511$.

Solomon, E., Borrow, J., and Goddard, A. D. (1991). Chromosome aberrations and cancer. Science 254: 1153-1160.

Stanbridge, E. J. (1990). Human tumor suppressor genes. Annu. Rev. Genet. 24: 615-657.

Telenius, H., Carter, N. P., Bebb, C. E., Nordenskjöld, M., Ponder, B. A. J., and Tunnacliffe A. (1992). Degenerate oligonucleotideprimed PCR: General amplification of target DNA by a single degenerate primer. Genomics 13: 718-725.

Trent, J. M., Rosenfeld, S. B., and Meyskens, F. L. (1983). Chromosome $6 \mathrm{q}$ involvement in human malignant melanoma. Cancer Genet. Cytogenet 9: 177.

Trent, J. M., and Thompson, F. H. (1987). Methods for chromosome banding of human and experimental tumors in vitro. Methods Enzymol. 151: 267-279.

Trent, J. M., Thompson, F. H., and Meyskens, F. L. (1989). Identification of a recurring translocation site involving chromosome 6 in human malignant melanoma. Cancer Res. 49: 420-423.

Trent, J. M., Stanbridge, E., McBride, H., Meese, E., Casey, G., Araujo, D., Witkowski, C., and Nagle, R. (1990). Tumorigenicity in human melanoma cell lines is controlled by introduction of human chromosome 6. Science 247: 568-571.

Vogelstein, B., Fearon, E. R., Kern, S. E., Hamliton, S. R., Preisinger, A. C., Nakamura, Y., and White, R. (1989). Allelotype of colrectal carcinomas. Science 244: 207-211. 